\title{
Overview of hospitalizations by ambulatory care sensitive conditions in the municipality of Cotia, Brazil*
}

\author{
PANORAMA DAS INTERNAÇÕES POR CONDIÇÕES SENSÍVEIS À ATENÇÃO PRIMÁRIA \\ NO MUNICÍPIO DE COTIA
}

\author{
PANORAMA DE LAS HOSPITALIZACIONES POR CONDICIONES SENSIBLES DE LA \\ ATENCIÓN PRIMARIA EN LA CIUDAD DE COTIA
}

\section{Renata Laszlo Torres ${ }^{1}$, Suely Itsuko Ciosak ${ }^{2}$}

\begin{abstract}
Objective: To describe the profile of Hospitalizations by Amulatory Care Sensitive Conditions (HACSC), in the Municipality of Cotia, from 2008 to 2012. Method: ecological, exploratory, longitudinal study with a quantitative approach. Data on HACSC, by age group and sex, were obtained from the Department of the Unified Health System. For data analysis descriptive statistics were used. Results: During the period, there were 46,676 admissions, excluding deliveries, $7,753(16.61 \%)$ by HACSC. The main causes were cerebrovascular diseases, $16.96 \%$, heart failure, $15.50 \%$, hypertension, $10.80 \%$ and infection of the kidney and urinary tract, $10.51 \%$. Regarding gender, HACSC occurred predominantly in males. There was a greater number of HACSC at extreme age ranges, especially in the elderly. Conclusion: Chronic diseases predominate among the leading causes of HACSC and there was no significant difference between sex.
\end{abstract}

\section{DESCRIPTORS}

Hospitalization

Primary Health Care

Quality of Health Care

Health evaluation

Public health nursing

\section{RESUMO}

Objetivo: Descrever o perfil das Internações por Condições Sensíveis à Atenção Primária (ICSAP), no Município de Cotia, entre 2008 e 2012. Método: Estudo ecológico, exploratório, longitudinal, de abordagem quantitativa. Dados sobre as ICSAP, segundo a faixa etária e sexo, foram obtidos no Departamento de Informática do Sistema Único de Saúde. Para a análise dos dados foi utilizada a estatística descritiva. Resultados: No período, houve 46.676 internações, excluindo os partos, sendo $7.753(16,61 \%)$ por ICSAP. As principais causas foram: doenças cerebrovasculares, 16,96\%; insuficiência cardíaca, 15,50\%; hipertensão, 10,80\%; e infecção do rim e trato urinário, $10,51 \%$. Quanto ao sexo, as ICSAP ocorreram predominantemente nos homens. Houve maior número de ICSAP nos extremos das faixas etárias, especialmente nos idosos. Conclusão: As doenças crônicas predominaram entre as principais causas de ICSAP e não houve diferença importante entre os sexos.

\author{
DESCRITORES \\ Hospitalização \\ Atenção Primária à Saúde \\ Qualidade da Assistência em Saúde \\ Avaliação em saúde \\ Enfermagem em saúde pública
}

\begin{abstract}
RESUMEN
Objetivo: Describir el perfil de las Hospitalizaciones por Condiciones Sensibles de la Atención Primaria (HCSAP), en el municipio de Cotia, entre 2008 y 2012. Método: Estudio ecológico, exploratorio, longitudinal con un enfoque cuantitativo. Los datos sobre HCSAP, por grupo de edad y sexo, se obtuvieron del Departamento del Sistema Único de Salud. Para el análisis de los datos se utilizaron estadísticas descriptivas. Resultados: Durante el período, hubo 46.676 admisiones, excluyendo entregas, 7.753 (16,61\%) por HCSAP. Las principales causas fueron las enfermedades cerebrovascular, 16,96\%, insuficiencia cardíaca, 15,50\%, hipertensión arterial $10,80 \%$ y infección del riñón y las vías urinarias, el $10,51 \%$. Cuanto al género, HCSAP ocurrió mayormente en los hombres. Un mayor número de HCSAP en grupos de edades extremas, especialmente en los ancianos. Conclusión: Las enfermedades crónicas predominan entre las principales causas de HCSAP y no hubo diferencia significativa entre los sexo.
\end{abstract}

\section{DESCRIPTORES \\ Hospitalización \\ Atención Primaria de Salud \\ Calidad de la Atención de Salud \\ Evaluación en Salud \\ Enfermería em salud pública}

*Extracted from the study "Panorama das Internações por Condições Sensíveis à Atenção Primária no município de Cotia" 1st Exhibition of Studies of the Graduate Program in Nursing, School of Nursing, University of São Paulo, 2013. ${ }^{1}$ Master's Student, School of Nursing, University of São Paulo, São Paulo - São Paulo, Brazil. ${ }^{2}$ Associate Professor, Department of Nursing in Community Health, School of Nursing, University of São Paulo, São Paulo - São Paulo, Brazil. 


\section{INTRODUCTION}

With the establishment of the Brazilian Public Healthcare System (SUS - Sistema Único de Saúde) by way of the 1988 Federal Constitution, principles and guidelines were highlighted, with an emphasis on universality, comprehensiveness, fairness, use of epidemiology in establishing priorities and allocating resources, and political and administrative decentralization, with an emphasis on decentralization of services to municipalities ${ }^{(1)}$. In this context, primary health care $(\mathrm{PHC})$, which possesses values that are in line with the principles and guidelines of the SUS ${ }^{(2)}$, is essential for the proper performance of the healthcare system.

In 1994, the Family Health Program, which was expanded into the Family Health Strategy Service (FHSS) in 2006, was developed in order to reorganize the healthcare model so that it would be in accordance with the precepts of the SUS ${ }^{(3)}$.

In this manner, over the decades of the 1990s and the 2000 s, in addition to the decentralization process and revision of the role of the managers of each branch of government, the strengthening of the PHC also occurred in Brazil.

In order to progress in the decentralization process and expand the activities of municipal healthcare management, ordinances were published which included monitoring and evaluation at the federal, state and municipal levels, emphasizing that municipalities are responsible for meeting the healthcare needs and demands of the population within their territories, with the responsible entity taking ownership of results, based on epidemiological criteria, while identifying priorities in the decision-making process in terms of allocation of resources ${ }^{(4-6)}$.

However, despite numerous advances in health policies in Brazil, challenges remain, including management, which must make use of information for decision making oriented towards programming and improving PHC. Considering that a health system focused on primary care achieves better outcomes for public health ${ }^{(2)}$, in many situations where this level is not assertive, hospitalizations occur for health problems that could be resolved before the need for hospitalization ${ }^{(4)}$.

These events are important indicators for evaluating the quality of care offered by way of PHC. With this purpose, in the late 1980s, the Ambulatory Care Sensitive Conditions (HACSC) ${ }^{(7)}$ indicator was developed in the United States. In the second half of the 1990s, the National Health Service (United Kingdom) proposed that this indicator be used for analysis of the quality of PHC; it has since been used for this purpose in countries that possess healthcare systems based on primary care ${ }^{(8)}$. Despite its usefulness, this indicator has limitations, such as the influence of organization of healthcare systems on PHC activities and sociodemographic conditions, which are beyond the control of $\mathrm{PHC}^{(9-10)}$.
In Brazil, the final list of HACSC was published in April 2008, after several stages of adaptation to local realities. The list consists of 19 diagnostic groups, totaling 120 categories of the ICD-10 (with three digits) and 15 subcategories (with four digits) $)^{(11)}$.

Using the Brazilian list of HACSC, we sought to investigate the panorama of hospital admissions in the city of Cotia, Brazil, because the healthcare system at this location was once considered an alternative model to the medical system centered on individual and curative care $^{(12)}$. Since the implementation of the FHSS, major oscillations in teams and population coverage have occurred for this service ${ }^{(13)}$, involving almost all public healthcare facilities under municipal management. Thus, this study may provide indications to management concerning the fragility of the healthcare needs of the population ${ }^{(10,14-15)}$.

\section{METHOD}

This is an ecological, exploratory study with a quantitative approach, using secondary data from the period between 2008 and 2012.

The conceptual theoretical frameworks chosen to illuminate the object of the study were: $\mathrm{PHC}$, as the organizer within the healthcare system, the communication center of the Healthcare Network (Redes de Atenção à Saúde - RAS) and the theory of social determination of the health-disease process, based on dialectical and historical materialism, which aims to articulate social and political processes, and the organization of society in respect to the emergence of risks or potentials that determine the process of disease and death ${ }^{(16)}$.

This study was conducted in the municipality of Cotia, located west of the Metropolitan Region of São Paulo, in the Healthcare Region of the Mananciais.

The municipality is $100 \%$ urbanized and has an area of $324.010 \mathrm{~km}^{2}$, with a population density of 622.55 inhabitants $/ \mathrm{km}^{2 ;}$ the resident population was 201,150 in $2010^{(17)}$.

With respect to urban infrastructure, in 2010, in the municipality of Cotia, garbage collection covered $99.3 \%$ of households, the supply of water through the general network reached $90.98 \%$ of households and the sewer system reached $52.9 \%$ of households ${ }^{(17)}$.

Regarding the healthcare sector, 49 public institutions are under municipal management: a department of health; three psychosocial care centers; 25 healthcare centers / a basic healthcare unit; one central healthcare regulatory agency; six specialized clinics/specialized outpatient clinics; two pharmacies; two polyclinics; four general emergency rooms; two units of health surveillance; two mobile units at the pre-hospital level for urgent care/ emergency; and a standard mobile unit ${ }^{(13)}$. 
The implementation of the FHSS in the municipality has had its ups and downs; in August 2003, there were three teams and the estimated coverage of the population was $6.56 \%$ of inhabitants. In the period from October 2003 to April 2004, this increased to five teams and a population coverage of $10.94 \%$ of the inhabitants. No team was registered from February to April 2008. Subsequently, a maximum of 11 teams was deployed from June 2011 to January 2012 , with a population coverage of $18.87 \%^{(13)}$.

The municipality depends on the Hospital Regional de Cotia (HRC); the hospital has 131 SUS beds and is considered to be midrange. It is managed by the state, and performs outpatient and inpatient care for cases of medium to high complexity ${ }^{(13)}$.

There is also the Hospital da Graça, a private institution under the management of the State Department of Health. This hospital has 80 SUS beds for chronic illness; it offers medium complexity healthcare for long-stay modalities, such as neurology, pulmonology and traumatology, being a center of reference for the Greater São Paulo Region.

The data were collected on the ACSC was based on the Brazilian ACSC list, obtained by way of the hospital information system of SUS (SIH-SUS, as per its acronym in Portuguese), relating to hospitalizations of residents in the municipality, according to age group and gender, in the period from 2008 to 2012.

Information related to HACSC was obtained from a file generated for definition and tabulation (DEF) based on the selection in the SIH-SUS of the respective codes. The application Tabwin version 3.5 was used (developed by DATASUS). The results were displayed by way of tables and charts, and descriptive statistics were used for data analysis.

There was no need for permission from the Research Ethics Committee, as it was secondary data available online.

\section{RESULTS}

In the municipality of Cotia, in the period 2008 to 2012, 46,676 hospitalizations occurred, excluding deliveries, being $7,753(16.61 \%)$ by HACSC (Table 1$)$.

When performing annual analysis of HACSC in relation to general admissions, excluding births, a fluctuation in the proportion of these hospitalizations becomes evident over the period, and a decrease in the amount in absolute terms, only in 2010. The greatest proportion and growth in HACSC occurred in 2009 (Table 1).

We noted an increase in absolute terms, in the general admissions, excluding births in each year of the study, accompanied by the increase in HACSC, except in 2010 (Table 1).
Table 1 - General admissions, excluding births; number, distribution and percentage change of hospitalizations by ambulatory care sensitive conditions, 2008 to 2012 - Cotia, SP, 2012

\begin{tabular}{ccccc}
\hline Year & $\begin{array}{c}\text { Hospitalizations } \\
\text { without deliveries }\end{array}$ & \multicolumn{2}{c}{ HACSC } & $\begin{array}{c}\text { Change } \\
\text { (previous year) }\end{array}$ \\
\hline & No. & No. & \% & \% \\
2008 & 4,458 & 706 & 15.84 & - \\
2009 & 9,333 & 1,721 & 18.44 & 143.77 \\
2010 & 10,374 & 1,642 & 15.83 & -4.59 \\
2011 & 10,964 & 1,840 & 16.78 & 12.06 \\
2012 & 11,547 & 1,844 & 15.97 & 0.22 \\
\hline Total & $\mathbf{4 6 , 6 7 6}$ & $\mathbf{7 , 7 5 3}$ & $\mathbf{1 6 . 6 1}$ & - \\
\hline
\end{tabular}

Source: SIH-SUS

With regard to gender, in 2008, 2009 and 2011 there was a predominance of male HACSC; in 2010, these admissions were nearly equivalent between genders, being slightly higher for women. It is noteworthy that in 2012, there was a reversal in the proportion of women making up these hospitalizations (Figure 1).

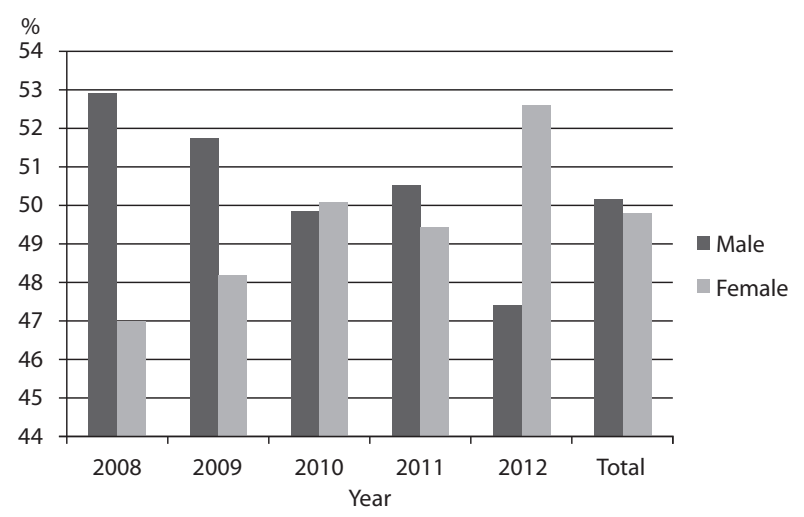

Source: SIH-SUS

Figure 1 - Proportion of hospitalizations by ambulatory care sensitive conditions, by gender, 2008 to 2012 - Cotia, SP, 2012

In regards to age, most patients hospitalized in the period were: 50 to 59 years, followed by the range of 60 to 69 years, 70 to 79 years, 80 years and over and 40 to 49 years (Figure 2).

We noticed that the range of 50 to 59 years had the highest proportion of HACSC throughout most of the period, except in 2012 when aged 60 to 69, who ranked third in 2008 and second from 2009 to 2011, went to the first position in terms of hospitalizations; the range of 70 to 79 ranked second in hospitalizations in 2008 and third from 2009 to 2012; the range of 40 to 49 years occupied fourth place in 2008 and fifth in 2009 to 2012, while the 80 years and older age group went to fourth position (Figure 2).

Regarding hospitalizations by groups of HACSC during the period from 2008 to 2012, the causes with representation above $10 \%$ were: cerebrovascular disease (16.96\%); heart failure $(15.50 \%)$; hypertension $(10.80 \%)$; and infection of the kidney and urinary tract (10.51\%) (Table 2). 


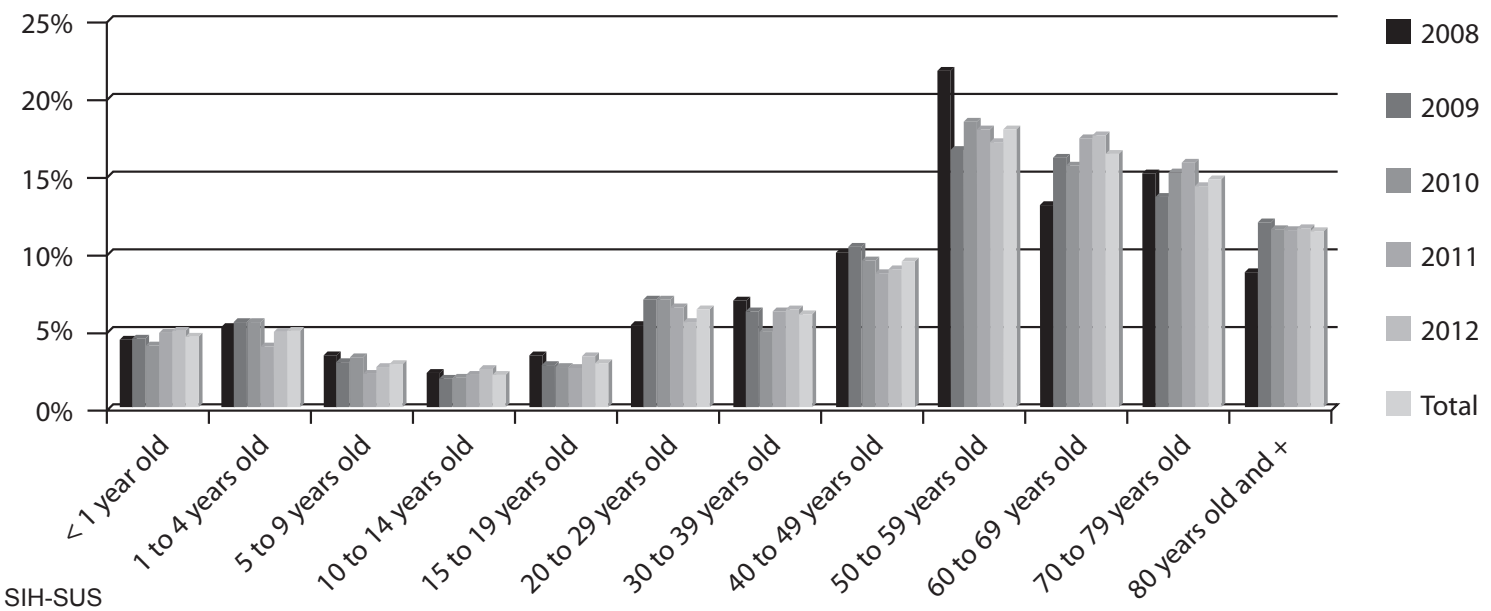

Figure 2 - Proportion of hospitalizations by ambulatory care sensitive conditions, by age group, 2008 to 2012 - Cotia, SP, 2012

Table 2 - Proportion of the hospitalizations by ambulatory care sensitive conditions of the residents in the municipality of Cotia, 2008 to 2012 - Cotia, SP, 2012.

\begin{tabular}{|c|c|c|c|c|c|c|}
\hline HACSC & 2008 & 2009 & 2010 & 2011 & 2012 & Total \\
\hline $\begin{array}{l}\text { Diseases preventable } \\
\text { by immunization and } \\
\text { sensitive conditions }\end{array}$ & 0.57 & 0.29 & 0.97 & 1.03 & 0.43 & 0.67 \\
\hline $\begin{array}{l}\text { Infectious gastroenteri- } \\
\text { tis and complications }\end{array}$ & 4.96 & 3.95 & 4.14 & 4.35 & 3.90 & 4.17 \\
\hline Anemia & 0.28 & 0.35 & 0.24 & 0.22 & 0.22 & 0.26 \\
\hline Nutritional deficiencies & 0.71 & 0.70 & 0.24 & 0.92 & 0.49 & 0.61 \\
\hline $\begin{array}{l}\text { Infections of the ear, } \\
\text { nose and throat }\end{array}$ & 1.13 & 2.61 & 1.83 & 1.25 & 1.84 & 1.81 \\
\hline Bacterial pneumonia & 1.13 & 0.87 & 1.40 & 1.25 & 3.42 & 1.70 \\
\hline Asthma & 3.54 & 3.72 & 3.59 & 2.17 & 2.60 & 3.04 \\
\hline Lung diseases & 5.10 & 4.82 & 6.94 & 6.96 & 9.27 & 6.86 \\
\hline Hypertension & 10.62 & 14.12 & 10.23 & 9.35 & 9.71 & 10.80 \\
\hline Angina & 6.23 & 4.53 & 3.35 & 6.14 & 4.61 & 4.84 \\
\hline Heart Failure & 11.61 & 16.50 & 16.50 & 17.28 & 13.39 & 15.50 \\
\hline $\begin{array}{l}\text { Cerebrovascular } \\
\text { Disease }\end{array}$ & 25.21 & 17.08 & 16.32 & 15.87 & 15.35 & 16.96 \\
\hline Diabetes mellitus & 6.23 & 5.52 & 6.52 & 6.85 & 6.29 & 6.29 \\
\hline Epilepsy & 4.25 & 4.71 & 6.21 & 3.70 & 3.15 & 4.37 \\
\hline $\begin{array}{l}\text { Infection of the kidney } \\
\text { and urinary tract }\end{array}$ & 8.92 & 8.13 & 9.50 & 10.82 & 13.94 & 10.51 \\
\hline $\begin{array}{l}\text { Infection of the skin } \\
\text { and subcutaneous tissue }\end{array}$ & 3.12 & 5.11 & 5.30 & 5.49 & 4.23 & 4.85 \\
\hline $\begin{array}{l}\text { Inflammatory disease of } \\
\text { female pelvic organs }\end{array}$ & 1.98 & 1.86 & 1.16 & 1.79 & 2.01 & 1.74 \\
\hline Gastrointestinal ulcer & 1.70 & 1.39 & 1.71 & 1.68 & 2.33 & 1.78 \\
\hline $\begin{array}{l}\text { Related to prenatal } \\
\text { diseases and birth }\end{array}$ & 2.69 & 3.72 & 3.84 & 2.88 & 2.82 & 3.24 \\
\hline
\end{tabular}

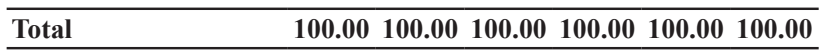

Source: SIH-SUS

There was no significant change in hospitalizations for diabetes mellitus or for infectious gastroenteritis and complications; diseases related to prenatal and birth showed a low proportion in HACSC, as well as hospitalizations for diseases preventable by immunization, which corresponded to one of the lowest, with a tendency to decrease (Table 2).

In the analysis of the evolution of the proportion of HACSC by year in 2008 and 2009, the leading cause of hospitalization was cerebrovascular disease, followed by heart failure and hypertension; whereas in 2010, cerebrovascular disease ranked second, with heart failure taking first position and hypertension remaining in third place. In 2011, heart failure and cerebrovascular disease remained in the same positions; however, infection of the kidney and urinary tract came to occupy third place, and hypertension occupied fourth place. In 2012, cerebrovascular disease returned to first position in the causes of hospitalizations, infection in the kidney and urinary tract became the second cause of hospitalization, heart failure moved into third position and hypertension remained in fourth position (Table 2).

Analyzing the main HACSC groups according to gender and age group, from 2008 to 2012, cerebrovascular disease accounted for $22.04 \%$ of hospitalizations for males and $11.85 \%$ for females, predominantly in the age group above 60 years (57. 11\%); heart failure accounted for $15.33 \%$ of hospitalizations in men and $15.68 \%$ in women, predominantly in the elderly above 60 years of age (66.39\%); hypertension was related to $10.85 \%$ of hospitalizations in males and $10.74 \%$ in females, predominantly over 60 years of age $(57.59 \%)$; and infection of the kidney and urinary tract corresponded to $6.30 \%$ of hospitalizations for males and $14.75 \%$ for women, concentrated in the age group of 20 to 59 years of age $(41.47 \%)$, followed by the age group of 60 years and older (35.71\%).

In 2008, cerebrovascular disease accounted for $30.48 \%$ of all hospitalizations in males and $19.28 \%$ in females, predominantly in the age group over 60 years of age $(51.12 \%)$; heart failure was related to $11.23 \%$ in males and $12.05 \%$ in women, accounting for $58.54 \%$ of hospitalizations in the elderly; hypertension accounted for $10.70 \%$ of hospitalizations for males and $10.54 \%$ for females, predominantly in the elderly (57.33\%); and infection of the kidney and urinary tract corresponded to $6.15 \%$ in males and $12.05 \%$ in women, accounting for $55.56 \%$ of hospitalizations in the group of 20 to 59 years of age. 
In 2009, cerebrovascular disease showed a decline in the proportion of hospitalizations in males, $23.34 \%$, and $10.36 \%$ in females, increasing the proportion in the elderly $(56.12 \%)$; heart failure increased representation in HACSC in both genders, reaching $15.71 \%$ in males and $17.35 \%$ in females, with an increase in the elderly $(65.14 \%)$; hypertension increased to $14.25 \%$ in males and $13.98 \%$ in females, with an increase in hospitalizations in the elderly (58.02\%); and infection of the kidney and urinary tract in men decreased to $4.94 \%$, and in to $11.57 \%$ in women, with a reduction in the age group of $20-59$ years $(41.43 \%)$, due to the significant increase in the elderly, from $12.70 \%$ in 2008 to $33.57 \%$ in 2009 .

In 2010, cerebrovascular disease showed slight variations and increased to $23.57 \%$ in males, while in females it decreased to $9.11 \%$, and $54.48 \%$ for the elderly; heart failure showed a slight increase in males, to $16.61 \%$, and slight decrease in females, to $16.40 \%$, with a slight reduction in the elderly (64.94\%); hypertension showed a significant decrease in the proportion of hospitalizations in both genders, reaching $9.65 \%$ in males and $10.81 \%$ in women, with a slight reduction in the elderly $(57.74 \%)$; and infection of the kidney and urinary tract in males decreased to $4.64 \%$, and increased in females to $14.34 \%$, which showed a higher proportion of hospitalization in the elderly $(41.67 \%)$, with a significant reduction in the age group of 20 to 59 years (35.26\%).

In 2011, hospitalizations for cerebrovascular disease in males decreased to $20.00 \%$, and increased in females, to $11.65 \%$, with an increase in the proportion of hospitalizations in the elderly (56.85\%); heart failure showed an increase in hospitalizations in both sexes, reaching $17.53 \%$ in males and $17.03 \%$ females, with a significant increase in hospitalizations of the elderly (71.70\%); hypertension showed a slight reduction in males, 9.57\%, and in females, $9.12 \%$, with a slight increase in the group over 60 years of age (58.72\%); and infection of the kidney and urinary tract in men showed an increase to $7.53 \%$, and a slight reduction in women, to $14.18 \%$, resuming the prevalence of hospitalizations in the group of 20 to 59 years of age (43.22\%).

Finally, in 2012, hospitalizations for cerebrovascular disease showed a slight reduction in men, $17.85 \%$, and an increase in women, to $13.09 \%$, with a significant increase in the elderly (64.66\%); heart failure demonstrated a significant reduction in both genders, reaching $13.16 \%$ in males and $13.61 \%$ in women, showing a significant reduction in HACSC in the elderly (65.18\%); hypertension increased in both genders, reaching $9.95 \%$ in males and $9.48 \%$ in females, reducing hospitalizations in the elderly $(55.87 \%)$; and infection of the kidney and urinary tract showed an increase in both genders, $8.01 \%$ in males and $19.28 \%$ in women, with a prevalence in the age group of 20 to 59 years $(40.47 \%)$, followed by the age group of 60 years and over (39.69\%).

\section{DISCUSSION}

The proportion of HACSC in total hospitalizations, excluding delivery, in the period from 2008 to 2012, was found to be within the limits shown in other studies of these hospitalizations ${ }^{(15,18)}$.

Deliveries should be excluded from total hospitalizations, as they are a natural outcome of pregnancy, not a pathology, and because they are influenced by the fertility rate, in addition to corresponding to admissions that occur only in a part of the female population ${ }^{(14)}$.

A higher increase in and proportion of HACSC occurred in the year 2009. The HCR was closed until October 2008 due to negotiation and completion of the state management contract; it reopened in November 2008, when the state's Department of Health effectively took over management of the hospital.

There was an increase, in absolute terms, of HACSC in virtually all years of the study, except in 2010, accompanied by an increase in overall hospitalizations, corroborating an overview study of HACSC in the state of São Paulo, in the period from 2000 to 2007, which showed that the regional departments of health $(\mathrm{RDH})$, where there was growth in overall hospitalizations, also showed an increase in HACSC, thus permitting the assumption that the increase in access to hospitalization may contribute to the increase of these hospitalizations ${ }^{(9)}$.

The same study revealed that there was an increase of $40.75 \%$ in HACSC in the RDH in the Greater São Paulo Region, from 2000 to $2007^{(9)}$. Considering that the city of Cotia belongs to the RDH of the Greater São Paulo Region, these results reinforce the results of the present study.

Contrasting with the results obtained in this study, which show fluctuations in the proportion of HACSC over the analysis period and an increase in the number of these hospitalizations, several studies show trends towards a

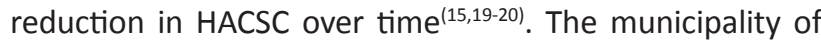
this study, however, has undergone fluctuations since its implementation in the number of teams and amount of population coverage of the FHSS, which may have affected the results of for HACSC, since studies show a reduction of hospitalizations when increasing coverage by the FHSS is present ${ }^{(9,15,21)}$. Note that the implementation of this strategy occurs differentially in various locations, being impacted by the structure, organizational arrangements and procedures for various types of work, making it impossible to generalize and thereby not positively impacting HACSC ${ }^{(22)}$.

During this period, the majority of HACSC involved men, except in 2010, when the proportions were almost equal, and in 2012, when there was a reversal of such hospitalizations in women. In 2010, there was a population growth of $11.26 \%$ in women, while in men the increase was $9.71 \%$; the coefficient of masculinity fell from 97.22 
to 95.87 men per 100 women. These facts may have provided a reason for the proportions of HACSC being almost equal between the genders in 2010. In 2011 and 2012, both genders showed a $1.99 \%$ increase, maintaining the coefficient of $95.87^{(17)}$, which does not justify the reversal of hospitalizations that occurred in 2012.

Several studies contradict these results, showing higher proportion of HACSC in women ${ }^{(19-20,23)}$.

There is a need to address gender issues involved in the proportions of HACSC, because it can contribute to knowledge of the actual reasons for the greater proportion of these hospitalizations in a particular gender ${ }^{(24)}$. For this, further analysis should be pursued. It is evident that the age groups that were hospitalized the most were over 40 years of age, with the larger proportion being represented by those over 50 years of age, which shows that, with aging, the number of HACSC increases.

Several studies corroborate these findings, reaffirming that children younger than four years of age ${ }^{(23)}$ and the elderly ${ }^{(10,21,23)}$ are the age groups most affected by HACSC.

Accompanying the profile with highest proportion of HACSC in the elderly, the causes with representation above $10 \%$ in the period were: cerebrovascular disease; heart failure; hypertension; and infection of the kidney and urinary tract. Except for infection of the kidney and urinary tract, other causes are chronic diseases, which affect the elderly population more.

Contradicting these results, a study undertaken in the city of Curitiba to describe the profile of HACSC from 2005 to 2007 showed a higher number of hospitalizations for angina pectoris, which occupied the seventh position of the leading causes of hospitalization in this study ${ }^{(25)}$.

Some studies include, among the leading causes of hospitalization, angina, infectious gastroenteritis and complications and bacterial pneumonia ${ }^{(18,23)}$, unlike the results obtained in this study. On the other hand, cerebrovascular disease, heart failure, infection in the kidney and urinary tract and pulmonary disease were among the leading causes of hospitalization in several studies ${ }^{(18,23,25)}$ converging with the results of this study.

The difference in hospitalizations for infectious gastroenteritis may be due to a comparison between different Brazilian regions, which have varying levels of access to healthcare services and professionals as well as variable living conditions ${ }^{(26)}$.

The low number of hospitalizations for infectious gastroenteritis and complications in the municipality being studied may be related to water being supplied through the general water system, which reached $90.98 \%$ of households in $2010^{(17)}$.

In the period from 2008 to 2012, diseases preventable by immunization and sensitive conditions comprised only
$0.67 \%$ of HACSC, occupying $17^{\text {th }}$ place, just ahead of anemia and nutritional deficiencies (Table 1).

Based on the conceptual framework for the construction of the Brazilian list of HACSC, hospitalizations, especially for vaccine-preventable diseases, should be avoided, or, rather, should be essentially eliminated by efficient and high-quality $\mathrm{PHC}^{(14)}$.

In a study with the objective of identifying the main HACSC at Hospital Geral de Pedreira and in basic healthcare units that demanded a greater number of hospitalizations, using data from 2008, there was no record of hospitalizations for diseases preventable by immunization and sensitive conditions, resembling the findings of this study ${ }^{(27)}$. According to the authors, this result suggests that prevention by immunobiologicals, a procedure historically performed by $\mathrm{PHC}$, is effective.

Regarding hospitalizations for diabetes, these occupied sixth position in the present study. The performance of the FHSS in regards to illnesses included in the list of HACSC may take varying amounts of time before having an impact on statistical changes ${ }^{(8)}$. In this way, the effects on hypertension and diabetes, for example, may take longer to have an impact, since the process of transformation of habits requires more time, being that the success of the team depends on the adherence of the users in terms of incorporating new life styles.

Diseases related to prenatal care and childbirth are diagnoses that historically are part of the approach and healthcare provided by $\mathrm{PHC}^{(9)}$. In the present study, these diagnoses occupied the $11^{\text {th }}$ position in hospitalizations, suggesting that the actions of PHC are effective for this condition.

Regarding the main reasons for HACSC, hospitalizations for cerebrovascular disease, hypertension, heart failure and chronic non-communicable diseases were prevalent in the elderly, over 60 years of age; hospitalizations due to infection in the kidney and urinary tract predominated in the age group of 20 to 59 years, except in 2010, when seniors were hospitalized more often for this condition.

The results indicated a high amount of HACSC by NCDs in the elderly in 2008, which is consistent with national studies ${ }^{(22-28)}$.

Other studies point to heart failure and cerebrovascular disease as the leading causes of HACSC in the elderly, which is consistent with the results of this study ${ }^{(22,28)}$.

Such studies are relevant because they may provide indications to management regarding problems in accessing the healthcare system, in its performance or lack of use of PHC services, signaling opportunities for improvement. This could become an indicator for monitoring and evaluation, enabling diagnosis of critical aspects in addition to directing and improving healthcare programs, while seeking to achieve the principles of the SUS $S^{(8-10,14-15,20)}$. 


\section{CONCLUSION}

This study presented an overview of HACSC in the city of Cotia, showing that the proportion of these hospitalizations corresponded to other studies, despite having shown an increase during the period, following the profile of general hospital admissions. Also being elaborated on were HACSC by gender, with men predominating for the most part during the period, and age group, with the highest rate of incidence in the group above 40 years of age.

Despite the usefulness of the indicator, to signal health problems that could be accompanied by PHC, thus avoiding hospitalization, there are limitations on its use for assessment of PHC; There are determinants of HACSC that are external to the powers of PHC that should be considered; among them, the very organization of the health-

\section{REFERENCES}

1. Brasil. Lei n. 8.080, de 19 de setembro de 1990. Dispõe sobre as condições para a promoção, proteção e recuperação da saúde, a organização e o funcionamento dos serviços correspondentes e dá outras providências. Diário Oficial da União, Brasília, 20 set. 1990. Seção 1, p. 18055.

2. Starfield B. Atenção Primária: equilíbrio entre necessidades de saúde, serviços e tecnologia. Brasília: UNESCO; 2002.

3. Brasil. Conselho Nacional de Secretários de Saúde. Atenção Primária - Seminário do CONASS para construção de consensos [Internet]. Brasília; 2004 [citado 2013 mar 12]. 44p. Disponível em: http://189.28.128.100/dab/docs/geral/ conass_documenta2.pdf

4. Brasil. Ministério da Saúde. Portaria GM n. 648, de 28 de março de 2006. Aprova a Política Nacional de Atenção Básica, estabelecendo a revisão de diretrizes e normas para a organização da Atenção Básica para o Programa Saúde da Família (PSF) e o Programa de Agentes Comunitários de Saúde (PACS) [Internet]. Brasília; 2006 [citado 2013 maio 13]. Disponível em: http://bvsms.saude.gov.br/bvs/publicacoes/ politica_nacional_atencao_basica_2006.pdf.

5. Brasil. Ministério da Saúde. Portaria GM n. 399, de 22 de fevereiro de 2006. Divulga o Pacto pela Saúde 2006 Consolidação do SUS e aprova as Diretrizes Operacionais do Referido Pacto [Internet]. Brasília; 2006 [citado 2013 maio 12]. Disponível em: http://dtr2001.saude.gov.br/sas/ PORTARIAS/Port2006/GM/GM-399.htm care system and sociodemographic conditions, which require increased knowledge of the reality in Cotia.

It is noted that there are social determinants of the health-disease process that show that the health sector is not the only sector responsible for addressing the health problems of individuals, as inter-sectorial actions for improving access to healthcare in priority populations and areas should be implemented.

Furthermore, the analysis of HACSC depends on administrative data (such as authorizations for hospitalization), which were not created for the study. Additionally, the SIH-SUS records only hospitalizations that occurred in the SUS, and a single patient may have been counted multiple times, by not identifying readmissions and transfers to other hospitals.

6. Brasil. Ministério da Saúde. Portaria GM n. 2.488, de 21 de abril de 2011. Aprova a Política Nacional de Atenção Básica, estabelecendo a revisão de diretrizes e normas para a organização da Atenção Básica, para a Estratégia Saúde da Família (ESF) e o Programa de Agentes Comunitários de Saúde (PACS) [Internet]. Brasília; 2011 [citado 2013 maio 20]. Disponível em: http://bvsms.saude.gov.br/bvs/saudelegis/ gm/2011/prt2488_21_10_2011.html.

7. Billings J, Zeitel L, LukomnikJ, Carey TS, BlankAE, Newman L. Impact of socioeconomic status on hospital use in New York City. Health Aff [Internet]. 1993 [cited 2013 Jan 11];12(1):162-73. Available from: http://content.healthaffairs.org/content/1/12/162.long

8. Elias E, Magajewski F. A Atenção Primária à Saúde no sul de Santa Catarina: uma análise das internações por condições sensíveis à atenção ambulatorial, no período de 1999 a 2004. Rev Bras Epidemiol [Internet]. 2008 [citado 2012 nov. 2];11(4):633-47. Disponível em: http://www.scielosp.org/pdf/rbepid/v11n4/10.pdf

9. Rehem TCMSB, Egry EY. Internações por Condições Sensíveis à Atenção Primária no Estado de São Paulo. Ciên Saúde Coletiva [Internet]. 2011 [citado 2013 mar. 4]; 16(12):4755-66. Disponível em: http://www.scielo.br/pdf/csc/v16n12/24.pdf.

10. Ansari Z, Haider SI, Ansari H, Gooyer T, Sindall C. Patient characteristics associated with hospitalisations for ambulatory care sensitive conditions in Victoria, Australia. BMC Health Serv Res [Internet]. 2012 [cited 2013 June 15];12:475. Available from: http://www.ncbi.nlm.nih.gov/pmc/articles/PMC3549737/

11. Brasil. Ministério da Saúde. Portaria n. 221, de 17 de abril de 2008. Publica em forma de anexo a lista brasileira de internações por condições sensíveis à atenção primária [Internet]. Brasília; 2008 [citado 2012 nov. 7]. Disponível em: http://dtr2001.saude.gov.br/sas/PORTARIAS/Port2008/ PT-221.htm 
12. Ibañez N. Sistema local de saúde de Cotia: estudo de caso [tese doutorado]. São Paulo: Faculdade de Saúde Pública, Universidade de São Paulo; 1990.

13. Brasil. Ministério da Saúde. DATASUS. Informações de Saúde: Rede Assistencial [Internet]. Brasília; 2013 [citado 2013 jun. 10]. Disponível em: http://www2.datasus.gov.br/ DATASUS/index.php?area $=0204$

14. Alfradique ME, Bonolo PF, Dourado I, Lima-Costa MF, Macinko J, Mendonça CS, et al. Internações por condições sensíveis à atenção primária: a construção da lista brasileira como ferramenta para medir o desempenho do sistema de saúde (Projeto ICSAP - Brasil). Cad Saúde Pública [Internet]. 2009 [citado 2013 fev. 12];25(6): 1337-49. Disponível em: http://www.scielo.br/pdf/csp/v25n6/16.pdf

15. Campos AZ, Theme-Filha MM. Internações por condições sensíveis à atenção primária em Campo Grande, Mato Grosso do Sul, Brasil, 2000 a 2009. Cad Saúde Pública [Internet]. 2012 [citado 2013 jul. 12];28(5):845-55. Disponível em: http://www.scielo.br/pdf/csp/v28n5/04.pdf

16. Fonseca RMGS, Bertolozzi MR. A epidemiologia social e a assistência à saúde da população. In: Fonseca RMGS, coordenadora. A classificação das práticas de enfermagem em saúde coletiva e o uso da epidemiologia social. Brasília: ABEN; 1997.

17. Instituto Brasileiro de Geografia e Estatística. IBGE Cidades. Cotia, SP [Internet]. Rio de Janeiro; 2013 [citado 2013 mar. 14]. Disponível em: http://www.cidades.ibge.gov.br/

18. Silva TS. Internações hospitalares segundo condições sensíveis à atenção primária no DF - análise dos anos de 2008 a 2012 [Internet]. Brasília: Faculdade de Ceilândia, Universidade de Brasília, 2013 [citado 2013 mar. 14]. Disponível em: http://bdm.bce.unb.br/handle/10483/6778

19. Boing AF, Vicenzi RB, Magajewski F, Boing AC, Moretti-Pires $R O$, Peres KG, et al. Redução das internações por condições sensíveis à atenção primária no Brasil entre 1998 - 2009. Rev Saúde Pública [Internet]. 2012 [citado 2013 mar. 14];46(2):359-66. Disponível em: http://www.scielosp.org/ $\mathrm{pdf} / \mathrm{rsp} / \mathrm{v} 46 \mathrm{n} 2 / 3709 . \mathrm{pdf}$

20. Rehem TCMSB, Ciosak SI, Egry EY. Internações por condições sensíveis à atenção primária no hospital geral de uma microrregião de saúde do município de São Paulo, Brasil. Texto Contexto Enferm [Internet]. 2012 [citado 2013 maio 13]; 21(3):535-42. Disponível em: http://www.scielo.br/pdf/ tce/v21n3/v21n3a07.pdf.
21. Fernandes VBL, Caldeira AP, Faria AA, Rodrigues Neto JF. Internações sensíveis na atenção primária como indicador de avaliação da Estratégia Saúde da Família. Rev Saúde Pública [Internet]. 2009 [citado 2013 mar. 14];43(6):928-36. Disponível em: http://www.scielo.br/pdf/rsp/v43n6/03.pdf.

22. Marques AP. Análise das causas de internação de idosos segundo a classificação de condições sensíveis à Atenção Primária: estudo da evolução temporal no estado do Rio de Janeiro [Internet]. Rio de Janeiro: Escola Nacional de Saúde Pública Sergio Arouca; 2012 [citado 2013 jun. 9]. Disponível em: $\quad$ http://bvssp.icict.fiocruz.br/lildbi/docsonline/get. php?id=2918

23. Pazó RG, Frauches DO, Galvêas DP, Stefenoni AV, Cavalcante ELB, Pereira-Silva FH. Internações por condições sensíveis à atenção primária no Espírito Santo: estudo ecológico descritivo no período 2005-2009. Epidemiol Serv Saúde [Internet]. 2012 [citado 2013 jun. 9];21(2):275-82. Disponível em: http://scielo.iec.pa.gov.br/ pdf/ess/v21n2/v21n2a10.pdf

24. Rehem TCMSB. Internações sensíveis à Atenção Primária: limites e possibilidades da lista brasileira de diagnósticos [tese doutorado]. São Paulo: Escola de Enfermagem, Universidade de São Paulo; 2011.

25. Rehem TCMSB, Oliveira MRF, Amaral TCL, Ciosak SI, Egry EY. Hospitalisations for ambulatory care sensitive conditions in a Brazilian metropolis. Rev Esc Enferm USP [Internet]. 2013 [cited 2013 Aug 15];47(4):884-90. Available from: http://www.scielo.br/pdf/reeusp/v47n4/en_0080-6234reeusp-47-4-0884.pdf

26. Oliveira BRG, Viera CS, Collet N, Lima RAG. Causas de hospitalização no SUS de crianças de zero a quatro anos no Brasil. Rev Bras Epidemiol [Internet]. 2010 [citado 2013 ago. 15]; 13(2): 268-77. Disponível em: http://www.scielo.br/ pdf/rbepid/v13n2/09.pdf

27. Torres RL, Rehem TCMSB, Egry EY, Ciosak SI. The panorama of ambulatory care sensitive conditions in district of São Paulo. Rev Esc Enferm USP [Internet]. 2011 [cited 2013 Feb 4];45(n.esp.2):1661-6. Available from: http://www.scielo. br/pdf/reeusp/v45nspe2/en_04.pdf

28. Junqueira RMP, Duarte EC. Internações hospitalares por causas sensíveis à atenção primária no Distrito Federal, 2008. Rev Saúde Pública [Internet]. 2012 [citado 2013 jun. 12];46(5):761-8. Disponível em: http://www.scielo.br/pdf/ rsp/v46n5/01.pdf

\section{Acknowledgments}

The National Council for Scientific and Technological Development - CNPq, for the Master's Degree Scholarship granted.

Correspondence addressed to: Suely Itsuko Ciosak Departamento de Enfermagem em Saúde Coletiva, Escola de Enfermagem da USP

Av. Dr. Enéas de Carvalho Aguiar, 419 - Cerqueira César CEP 05403-000 - São Paulo, SP, Brazil

E-mail: siciosak@usp.br 